\title{
Effect of light treatment on the ripening of banana fruit during postharvest handling
}

\author{
İbrahim Sani Özdemir ${ }^{\star}$ \\ Tübitak Marmara Research Centre, Food Institute, P.O. Box 21, 41470, Gebze, Kocaeli, Turkey
}

Received 22 December 2014 - Accepted 28 October 2015

\begin{abstract}
Introduction. In this study, the effect of continuous light treatment $\left(24 \mu \mathrm{mol} \mathrm{m}^{-2} \mathrm{~s}^{-1}\right)$ on the ripening of banana fruit [Musa spp. (AAA group, Cavendish subgroup) cv. Grand Nain] during postharvest handling was investigated. Materials and methods. The changes in physiological and physical parameters related to banana ripening such as the respiration rate, ethylene production rate, weight, colour, texture and sugar content were analysed during storage. Results and discussion. Light treatment accelerated the ripening of bananas, which was characterised by a shortened pre-climacteric period. Light-treated bananas reached a respiratory climacteric peak 8 days earlier than bananas stored in the dark. Similar delays were also observed in the onset of climacteric ethylene rise, colour change, texture loss and soluble sugar accumulation between bananas stored under continuous light and darkness. Light treatment led to excessive weight loss in bananas. At the climacteric peak, respiration and ethylene production rates were significantly higher in light-treated bananas than bananas stored in the dark. Also, significantly higher amounts of soluble sugars were accumulated in light-treated bananas than in bananas stored in the dark. Conclusion. Light treatment can be used as a method for accelerating ripening of green bananas, especially during retail display, in order to provide consumers with fruits at their best eating quality.
\end{abstract}

Keywords: banana / Musa spp. / lighting / ripening stage / retail display / shelf life

Résumé - Effet de la lumière sur le mûrissement de la banane au cours de sa manutention postrécolte. Introduction. L'effet de la lumière en continu $\left(24 \mu \mathrm{mol} \mathrm{m}^{-2} \mathrm{~s}^{-1}\right)$ a été étudié sur le mûrissement de la banane [Musa spp. (Groupe AAA, sous-groupe Cavendish) cv. Grande Naine] au cours de la manutention post-récolte. Matériels et méthodes. Les modifications des valeurs des paramètres physiologiques et physiques liés au mûrissement des bananes ont été suivies pendant le stockage : le taux de respiration, le taux de production d'éthylène, le poids, la couleur, la texture et la teneur en sucres des fruits. Résultats et discussion. Le traitement lumineux a accéléré le mûrissement des bananes, ainsi caractérisé par une période de pré-climactérique plus courte. Les bananes traitées à la lumière ont atteint le pic climactérique respiratoire 8 jours plus tôt que les bananes stockées à l'obscurité. Des retards similaires ont également été observés dans l'apparition du pic climactérique d'éthylène, le changement de couleur, la perte de texture et l'accumulation des sucres solubles, entre les bananes stockées à la lumière et dans l'obscurité continue. Le traitement lumineux a conduit à une importante perte de poids des bananes. À l'apogée du pic climatérique les taux respiratoire et de production d'éthylène étaient significativement plus élevés pour les bananes éclairées que pour les bananes stockées à l'obscurité. En outre les teneurs en sucres solubles étaient significativement plus élevées dans les bananes traitées à la lumière que dans celles stockées à l'obscurité. Conclusion. La lumière peut être utilisée comme un traitement permettant d'accélérer le mûrissement des bananes vertes en particulier lors de la vente au détail afin de proposer aux consommateurs des fruits de meilleure qualité alimentaire.

Mots clés : banane / Musa spp. / traitement lumineux / mûrissement des fruits / vente au détail / aptitude au stockage

\section{Introduction}

Postharvest quality of fruits and vegetables can be maintained for prolonged durations by controlling environmental

\footnotetext{
* Corresponding author:

ibrahim.ozdemir@tubitak.gov.tr;

ibrahim.ozdemir@yahoo.com
}

factors such as temperature, humidity and the composition of the surrounding atmosphere. As an important environmental factor, the effect of light on the postharvest quality of fresh produce has been overlooked in postharvest research until recently. In the last decade, an increasing amount of research work has been published concerning the effect of light exposure on the postharvest quality of fresh produce during storage, either packed or not [1-3]. The rationale behind these studies 
was mainly to understand the physiological basis of produce responses to light exposure, which would provide useful clues for controlling the light environment of fresh produce during postharvest handling, with an ultimate aim of prolonging the shelf life. On the basis of accumulated scientific knowledge, some patented practical applications have already appeared on the market such as illuminated vegetable drawers for prolonging the shelf life of fruit and vegetables [4-6].

The literature in this field reveals the fact that commodities differ in their response to light exposure. It has been reported that light exposure could beneficially affect the nutritional quality of fresh produce such as spinach $[7,8]$, fresh-cut romaine lettuce [3], tomato [9], broccoli florets [2,10], fresh-cut celery [11] and cauliflower [12]. On the other hand, compared with storage under continuous darkness, light treatment was found to result in quality deterioration in chard [13], broccoli and cauliflower [14], ready-to-eat friariello campano (Brassica rapa L. subsp. sylvestris) [15], asparagus [16], leek [1], freshcut romaine lettuce (Lactuca sativa L. var. longifolia) [17], fresh-cut spinach [7], basil leaves [18], lamb's lettuce (Valerianella locusta L.) [19], and radish greens [20], mainly due to excessive water loss and cut surface browning.

Banana is one of the most popular tropical fruit, widely consumed throughout the world. It shows a climacteric ripening pattern which is characterised by a rapid increase in the ethylene production and respiration rate through the course of ripening. Banana ripening includes several physiological changes such as change in colour from green to yellow, starch degradation, increase in soluble sugar content, increase in aroma compounds and texture loss, which substantially affect the consumer appeal. Therefore, the effect of environmental conditions such as temperature [21], humidity [22] and atmospheric composition $[23,24]$ on the ripening of banana fruit during postharvest handling has been extensively studied and optimised for different varieties. However, to our knowledge no research has been published concerning the effect of light exposure on banana ripening during postharvest handling.

Therefore, the aim of this study was to investigate the effect of continuous light treatment on the ripening of banana fruit during postharvest handling in comparison with dark storage. For this purpose, the changes in some physical and biochemical parameters related to banana ripening such as the weight loss, peel colour, respiration rate, ethylene production rate, texture and soluble sugar content were analysed through the course of banana fruit ripening under continuous white light treatment at $24 \mu \mathrm{mol} \mathrm{m}{ }^{-2} \mathrm{~s}^{-1}$ and darkness at $22 \pm 1^{\circ} \mathrm{C}$.

\section{Materials and methods}

\subsection{Plant material}

Banana fruit [Musa spp. (AAA group, Cavendish subgroup) cv. Grand Nain] at the green mature stage (Stage 1 according to the banana colour index) were purchased from a commercial wholesaler.

\subsection{Experimental set-up}

Banana hands were cut into fingers and they were sorted for defects. Banana fingers were then selected for uniformity of size and colour. Each finger was marked and individually weighed. Banana fingers were then placed in plastic trays, containing three fingers each. Humid paper towels were put in the trays to generate saturating humidity and trays were covered with macro-perforated plastic film in order to maintain high humidity around the banana fingers and avoid carbon dioxide and ethylene accumulation. The prepared trays were placed under two lighting conditions: (i) continuous white light (LR), and (ii) darkness (DR). A high-pressure sodium lamp was used for light treatment. The distance from the light source to the fruit surface (approximately $2 \mathrm{~m}$ ) was adjusted in such a way as to obtain a photon flux density (PFD) of $24 \mu \mathrm{mol} \mathrm{m}^{-2} \mathrm{~s}^{-1}$ on the fruit surface, measured by PFD sensor (Minitest, Tartes, Turkey). It was observed that light exposure causes radiative heating on the fruit surface compared with bananas stored in the dark, which results in a local temperature rise of $1.5^{\circ} \mathrm{C}$. Therefore, in order to compensate for this temperature difference, DR and LR bananas were stored in separate cabinets set at $22.0 \pm 1.0^{\circ} \mathrm{C}$ and $20.5 \pm 1.0^{\circ} \mathrm{C}$, respectively. On each sampling day three fingers from each lighting condition were randomly selected and the weight, peel colour, respiration rate, ethylene production rate and texture of each finger were measured. Then, the peel and fruit pulp were separated, sliced into small pieces and immediately used for soluble sugar content analysis.

\subsection{Weight loss}

On each sampling day three fruits from different lighting conditions were weighed and the difference from their initial weight was expressed as the percent decrease from the initial weight.

\subsection{Peel colour}

The peel colour of the banana fruit was measured by using a computer vision system (CVS) (VeriVide, UK). The system consisted of a closed cabinet which was illuminated with two D65 lamps through reflective plates in diffuse mode. The photo of the fruit was taken from the top of the cabinet using a Nikon D90 digital camera equipped with a $35 \mathrm{~mm}$ Nikkor lens. Before taking the image, a white balance of the camera was made and calibrated by using a colour chart provided by the manufacturer of the CVS. The images were taken at a shutter speed of $1 / 10$ with 6.3 aperture and 200 sensitivity. The captured raw image was transmitted to the computer for colour measurement using the colour clustering feature of the DigiEye Software. The software calculated the colour of the selected fruit surface by taking the average CIE $L^{*}, a^{*}$ and $b^{*}$ values of each pixel of the fruit image. The $L^{*}$ value represents brightness and darkness, the $a^{*}$ value indicates greenness or redness as the value increases from negative to positive, and $b^{*}$ represents 
blue or yellow. The hue angle $\left(\mathrm{h}^{\circ}\right)$ was calculated according to the following equation:

$$
h^{\circ}=\arctan \left(b^{*} a^{*-1}\right)
$$

\subsection{Respiration and ethylene production rate measurement}

The respiration and ethylene production rates of banana fruits were measured by the glass jar method. According to this method, banana fingers were placed individually in 1-L airtight glass jars equipped with a septum on their lids for gas sampling. On each sampling day, three banana fingers from each lighting condition, DR and LR, were analysed.

Carbon dioxide concentrations were analysed by a gas chromatograph system (Agilent T 3000, SRA Instruments, France) consisting of an 8-m Poraplot- $U$ capillary column at $50{ }^{\circ} \mathrm{C}$ with helium as a carrier gas at a pressure of $28 \mathrm{psi}$ and equipped with a thermal conductivity detector. The GC was equipped with a vacuum pump which permits automated gas sampling through a needle fixed on the apparatus. The instrument was capable of taking a $1-\mu \mathrm{L}$ gas sample from the jar headspace. The respiration rate was expressed as mmol $\mathrm{CO}_{2} \mathrm{~kg}^{-1} \mathrm{~h}^{-1}$.

For ethylene measurement, a 1-mL sample was taken from the headspace of the jars and injected into a gas chromatograph (Perkin Elmer) equipped with a FID detector and HPPlotQ $(30 \mathrm{~mm} \times 15 \mathrm{~m} \times 20 \mu \mathrm{m})$ column. The column, injector and detector temperatures were $60{ }^{\circ} \mathrm{C}, 120{ }^{\circ} \mathrm{C}$ and $155^{\circ} \mathrm{C}$, respectively. Helium was used as a carrier gas at a flow rate of $1.6 \mathrm{~mL} \mathrm{~min}{ }^{-1}$. The limit of detection for ethylene in these analytical conditions was $0.2 \mathrm{ppm}$.

\subsection{Texture analysis}

Fruit firmness was analysed with a TA.XTplus Texture Analyser (Stable Micro Systems, UK) with a 2-mm-diameter needle probe attached to a 50-kg load cell, and the peel was punctured at a speed of $1 \mathrm{~mm} \mathrm{~s}^{-1}$ to a depth of $4 \mathrm{~mm}$. Measurements were made on 2-cm-thick slices taken from the middle section of the fruit. Each fruit slice was punctured on both sides in the equatorial region. One measurement was also made on the pulp by placing the slice on its cut surface. The hardness of the fruit was defined as the maximum force needed to puncture the tissue. The data were expressed in gram force (gf).

\subsection{Sugar content}

Soluble sugars were extracted by grinding $10 \mathrm{~g}$ frozen pulp or peel tissue in $40 \mathrm{~mL}$ distilled water at $18{ }^{\circ} \mathrm{C}$. The mixture was centrifuged at $4,000 \times g$ for $8 \mathrm{~min}$. The sample was filtered with a $0.45-\mu \mathrm{m}$ pore filter and $10 \mu \mathrm{L}$ sample was injected into the high-performance liquid chromatography (HPLC) system (Shimadzu, LC10A 2000, Japan) using 80/20\% acetonitrile/water solution as a solvent at a flow rate of $2 \mathrm{~mL} \mathrm{~min}^{-1}$. The system consisted of a refractive index detector and C-18

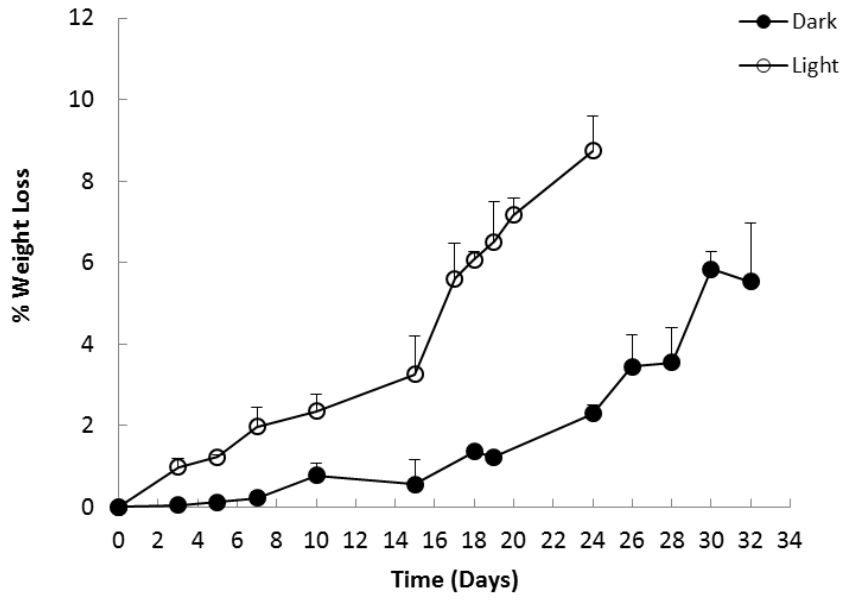

Figure 1. Change in the percent weight loss of banana fruits during postharvest storage under continuous light treatment of $24 \mu \mathrm{mol} \mathrm{m}{ }^{-2} \mathrm{~s}^{-1}(\circ)$ and darkness $(\bullet)$ at $20.5 \pm 1.0{ }^{\circ} \mathrm{C}$ and $22.0 \pm$ $1.0^{\circ} \mathrm{C}$, respectively. Data are the means \pm standard deviations $(n=3)$. The vertical bars indicate standard deviations.

Ace $250 \times 4.6 \mathrm{~mm} 5-\mu \mathrm{m}$ column. Fructose, glucose and sucrose were identified and quantified by comparison with the retention time and integrated peak areas of sugar standards and the results were expressed in $\mathrm{g} 100 \mathrm{~g}^{-1}$ fresh weight $(\mathrm{FW})$.

\subsection{Statistical analysis}

All analyses were carried out in triplicate corresponding to three individual banana fruits and mean differences were analysed by one-way ANOVA followed by the post-hoc Tukey HSD test at a significance level of $P<0.05$.

\section{Results and discussion}

\subsection{Weight loss}

The change in the weight of banana fruits during postharvest storage under different lighting conditions is shown in figure 1. Bananas stored under continuous white light (LR) lost significantly $(P<0.05)$ more weight than bananas stored under darkness (DR). After 24 days of storage, LR bananas lost $8.7 \pm 0.8 \%$ of their initial weight, whereas DR bananas lost only $5.5 \pm 1.4 \%$ after 32 days of storage. Similar observations were also reported for chard [4], broccoli and cauliflower [14], ready-to-eat friariello campano [15], asparagus [16], leek [1], fresh-cut romaine lettuce [17], fresh-cut spinach [7], and radish greens [20], which lost more weight when stored under light than darkness. The excessive weight loss observed in light-treated bananas might be attributed in part to the local temperature rise on the fruit surface as a result of radiative heating caused by light exposure. Preliminary measurements showed that in our experimental conditions light exposure caused only $1.5^{\circ} \mathrm{C}$ of temperature rise on the surface of LR bananas compared with DR bananas. In order to compensate for this temperature difference between LR 


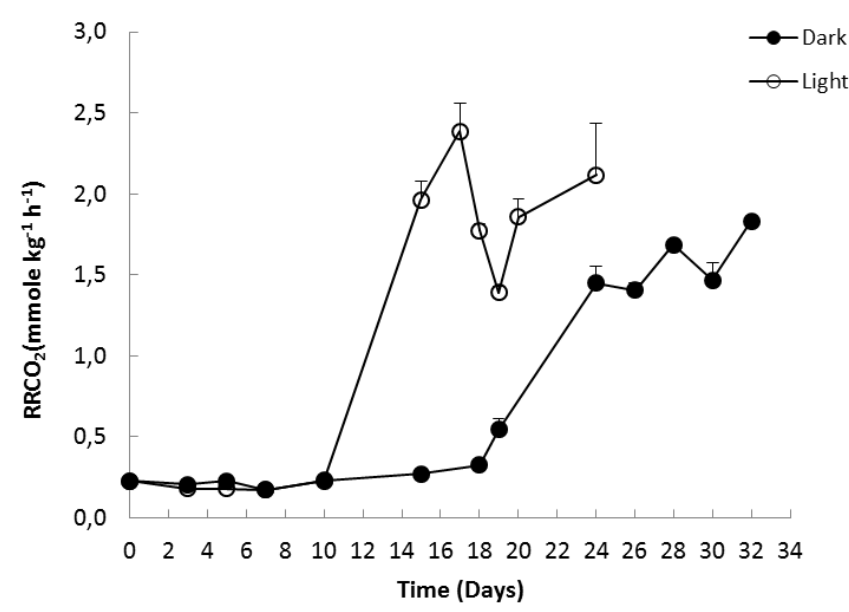

Figure 2. Change in the respiration rate $\left(\mathrm{RRCO}_{2}\right)$ of banana fruits during postharvest storage under continuous light treatment of $24 \mu \mathrm{mol} \mathrm{m}{ }^{-2} \mathrm{~s}^{-1}$ (०) and darkness $(\bullet)$ at $20.5 \pm 1.0{ }^{\circ} \mathrm{C}$ and $22.0 \pm$ $1.0^{\circ} \mathrm{C}$, respectively. Data are the means \pm standard deviations $(n=3)$. The vertical bars indicate standard deviations.

and DR bananas, fruits were stored at $20.5^{\circ} \mathrm{C}$ and $22.0{ }^{\circ} \mathrm{C}$, respectively. However, the weight loss in LR bananas was still more marked than DR bananas during the whole period of storage. Another possible reason for the excessive weight loss in LR bananas might be light-induced stomatal aperture, resulting in transpiration. Johnson and Brun [26] observed $646 \pm$ 142 stomata $\mathrm{cm}^{-2}$ on the surface of Cavendish bananas and demonstrated that under high relative humidity (90\%) green mature banana fruits can resume photosynthetic activity upon exposure to light.

\subsection{Respiration and ethylene production rates}

At the green mature stage, the respiration rate $\left(\mathrm{RR}_{\mathrm{CO} 2}\right)$ of bananas was around $0.2 \mathrm{mmol} \mathrm{kg} \mathrm{k}^{-1} \mathrm{~h}^{-1}$ (figure 2), which is a very low level. In LR bananas the respiration rate started to increase after 10 days of storage and exhibited a respiratory climacteric peak on the $17^{\text {th }}$ day of storage. Then, $\mathrm{RR}_{\mathrm{CO} 2}$ decreased until the $20^{\text {th }}$ day, followed by an increase until the end of the storage period. Compared with LR bananas, the respiratory activity of DR bananas was considerably slower and the onset of respiratory increase was delayed by approximately 8 days. In DR bananas the respiration rate started to increase after 18 days of storage and this increasing trend continued during the whole storage period without showing any distinct climacteric peak. The ethylene production rate of LR bananas showed a concomitant increase with the respiration rate, and two successive ethylene peaks were observed on the $17^{\text {th }}$ and $20^{\text {th }}$ days of storage, with the latter being more marked than the first one (figure 3). Similar results were reported by Zhu et al. [26] for naturally ripened 'Brazil' bananas, which showed two successive ethylene peaks during the course of ripening. In DR bananas the ethylene production rate also showed a parallel increase with the respiration rate. However, unlike LR bananas, only one ethylene peak was observed on the $24^{\text {th }}$ day of storage, and the ethylene production rate steadily decreased until the end of the storage period.

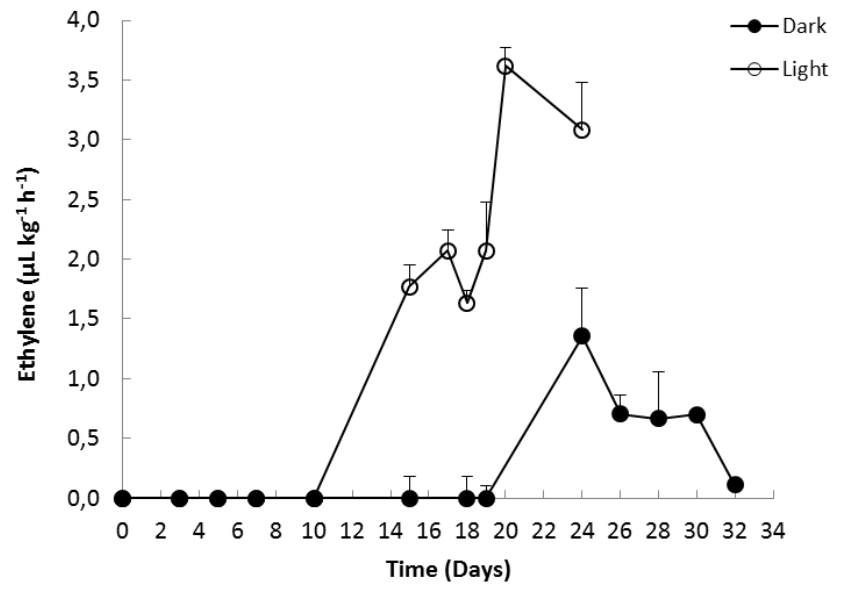

Figure 3. Change in the ethylene production rate of banana fruits during postharvest storage under continuous light treatment of $24 \mu \mathrm{mol} \mathrm{m}{ }^{-2} \mathrm{~s}^{-1}$ (०) and darkness $(\bullet)$ at $20.5 \pm 1.0{ }^{\circ} \mathrm{C}$ and $22.0 \pm$ $1.0^{\circ} \mathrm{C}$, respectively. Data are the means \pm standard deviations $(n=3)$. The vertical bars indicate standard deviations.

The shortened pre-climacteric period in LR bananas can be partly attributed to the increased weight loss, which was previously reported as an important factor which can accelerate banana ripening [21,22]. Finger et al. [22] demonstrated that excessive weight loss shortened the pre-climacteric period and induced a progressive decrease in the maximal rates of respiration and ethylene production rates of Cavendish bananas. However, contrary to these findings, in this study the respiration and ethylene production rates of LR bananas, which showed a higher degree of weight loss, were about 1.7 and 2.6 times higher than those of DR bananas. The effect of continuous light treatment on the oxidative status of banana might be another reason for the accelerated ripening. In apples, continuous light treatment was found to induce membrane lipid peroxidation and accelerate ripening [27]. Continuous light treatment is known to elevate the oxidative status in photosynthetic plant tissues and can be perceived as a stress factor [28]. Respiration and ethylene production rates of plant tissues can be stimulated as a response to several biotic and abiotic stress factors [29]. Thus, it might be expected that continuous light treatment increased the rate of oxidative reactions in banana to a level beyond the capacity of the antioxidant defence system which, in turn, stimulated ethylene biosynthesis and ripening.

\subsection{Sugar content}

In fruit, starch is broken down through biochemical reactions catalysed by enzymes such as amylase, glycosidase, phosphorylase, sucrose synthase and invertase, resulting in an increase in the levels of soluble sugars, mainly sucrose, glucose and fructose [30,31]. At the green mature stage the fructose, glucose and sucrose contents of the banana pulp and peel were $0.11 \pm 0.02,0.08 \pm 0.02$, and $0.37 \pm 0.01{\mathrm{~g} 100 \mathrm{~g}^{-1} \mathrm{FW}}^{\mathrm{F}}$ for pulp and $0.15 \pm 0.02,0.07 \pm 0.03$, and $0.56 \pm 0.01 \mathrm{~g}$ $100 \mathrm{~g}^{-1} \mathrm{FW}$ for peel, respectively (figure 4). As expected, as the fruits matured, the pulp fructose and glucose contents 


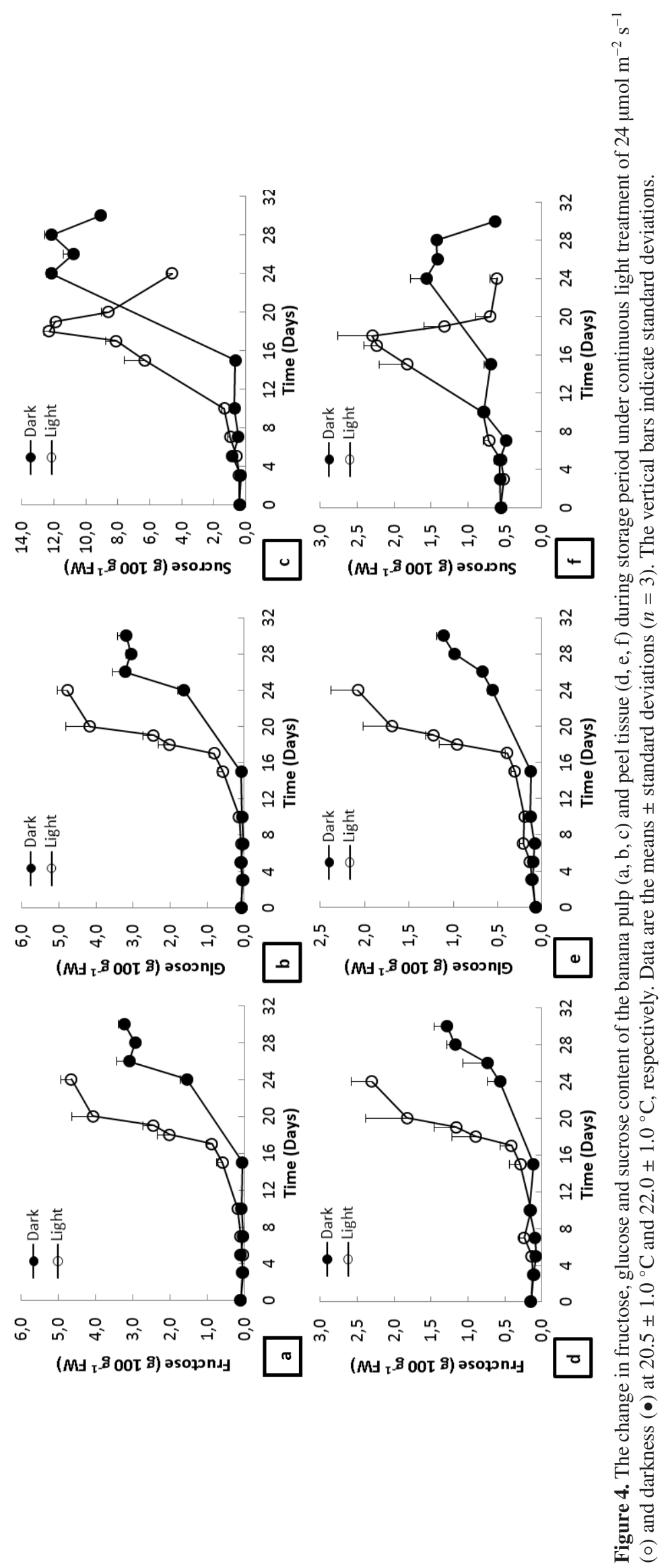


showed a steady increase and reached their maximum values

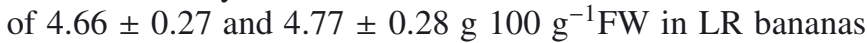
after 24 days and $3.22 \pm 0.18$ and $3.18 \pm 0.24{\mathrm{~g} 100 \mathrm{~g}^{-1} \mathrm{FW}}$ in DR bananas after 30 days of storage, respectively. Fructose and glucose content in the peel tissue increased in a similar manner to those in the pulp tissue during storage but the values were almost two-fold lower in the peel tissue. The fructose and glucose contents of the pulp and peel were significantly $(P<0.05)$ higher in LR than DR bananas. The sucrose content of the pulp and peel tissue in LR bananas increased until the $18^{\text {th }}$ day and sharply decreased thereafter. Regarding DR bananas, the sucrose content of the pulp and peel tissue started to increase after the $15^{\text {th }}$ day and reached its maximum level on the $24^{\text {th }}$ day. Subsequently, the sucrose content decreased at a slower pace compared with LR bananas. It is noteworthy that in both LR and DR bananas, the pattern of change in sucrose content was parallel in peel and pulp tissues and reached its maximum at the same time as the respiratory climacteric peak. This observation is in line with the previous literature $[32,33]$. It has been postulated that the conversion of starch to sucrose during banana ripening needs energy, and the necessary ATP in harvested bananas is supplied primarily through mitochondrial oxidative phosphorylation [32]. Moreover, it was reported that the climacteric rise and sugar accumulation in banana is strongly linked and sucrose does not accumulate in bananas in the absence of an increase in respiration [33]. The results of this study also showed that a higher amount of soluble sugars was accumulated in LR bananas than DR bananas at comparable maturity stages. This observation is important from an organoleptic point of view because it indicates that LR bananas are sweeter than DR bananas, which is an important criterion for consumer acceptance [34].

\subsection{Colour}

The change in the peel colour from green to yellow is the foremost parameter used for determining the ripening stage of bananas. Banana ripening is divided into 7 distinct maturity stages based on peel colour, which is well accepted by the trade industry [35]. In this study, peel colour was measured objectively by a computer vision system. The CIE $L^{*} a^{*} b^{*}$ colour space was used to characterise the colour of banana fruit. The hue angle $\left(\mathrm{h}^{\circ}\right)$ of the bananas started to decrease steadily with the onset of the respiratory rise after 10 and 18 days of storage from $108.8 \pm 1.5$ to $74.7 \pm 0.8$ and $85.2 \pm 1.8$ for LR and DR bananas, respectively (figure 5). During ripening, as a result of the disintegration of the thylakoid membrane and the degradation of the chlorophyll by chlorophyllase and oxidase enzymes, the green colour of the banana peel gradually disappears and reveals yellow carotenoid pigments [36]. The results of this study clearly showed that continuous light treatment accelerated the degreening of the bananas. It has been reported that continuous light treatment of $12 \mu \mathrm{mol} \mathrm{m}{ }^{-2} \mathrm{~s}^{-1}$ reduced yellowing of broccoli florets compared with darkness. Similar results have also been reported for basil leaves exposed to low-intensity white light $\left(30-37 \mu \mathrm{mol} \mathrm{m}^{-2} \mathrm{~s}^{-1}\right)$ for $2 \mathrm{~h} \mathrm{day}^{-1}$ [18]. The discrepancy between our results and those of Costa et al. [18] and Büchert et al. [2] might have arisen

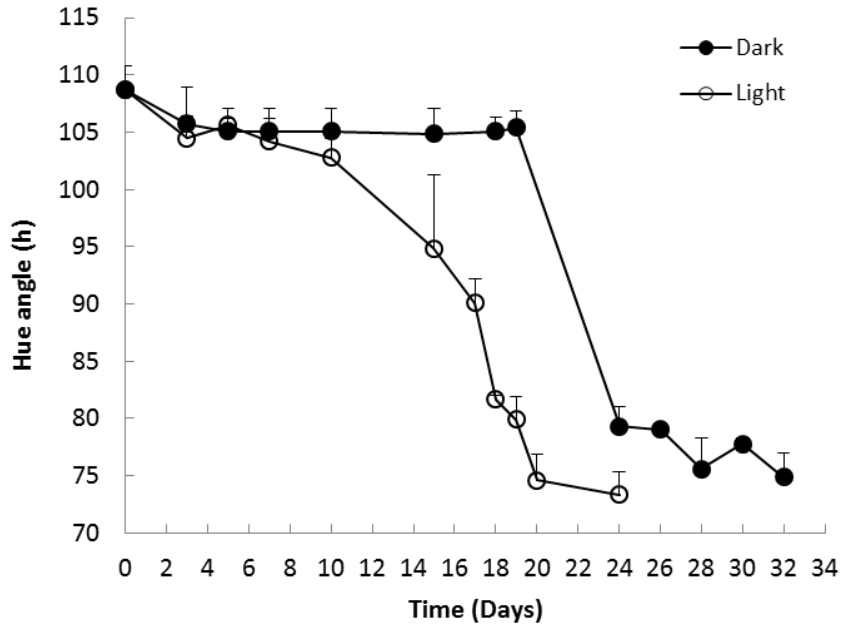

Figure 5. Change in the Hue angle $\left(h^{\circ}\right)$ of banana fruits during postharvest storage under continuous light treatment of $24 \mu \mathrm{mol} \mathrm{m}{ }^{-2} \mathrm{~s}^{-1}$ (०) and darkness $(\bullet)$ at $20.5 \pm 1.0{ }^{\circ} \mathrm{C}$ and $22.0 \pm$ $1.0^{\circ} \mathrm{C}$, respectively. Data are the means \pm standard deviations $(n=3)$. The vertical bars indicate standard deviations.

from the difference between the light intensities, exposure periods and tissue types used in these studies.

\subsection{Firmness}

Tissue strength is another physical parameter which is closely related to the ripening of bananas. In fruit pulp, the cell wall constitutes $\sim 35 \%$ pectic polysaccharides, and fruit softening is associated with changes in the pectic fraction of the middle lamella and cell wall, which is attributed mainly to the action of several enzymes such as polygalacturonase, pectin methylesterase and pectate lyase [37]. As can be seen in figure 6, loss of tissue strength was faster in LR than DR bananas. In both LR and DR bananas, pulp strength started to decrease with the onset of the climacteric rise. In LR bananas the pulp strength decreased to $78 \%$ of its initial value after 15 days of storage. In DR bananas, the extent of the texture loss in the pulp was similar to LR bananas, with 8 days of delay. Regarding peel strength, DR bananas were significantly firmer $(P<0.05)$ than LR bananas after the onset of the climacteric rise, and this was valid even for the advanced maturity stage. This difference might be owed to the excessive weight loss observed in LR bananas, which could lead to tissue shrinkage and reduced tissue strength.

\section{Conclusion}

Compared with bananas stored in the dark, continuous light treatment accelerated the natural ripening of harvested bananas, as it was characterised by a shortened pre-climacteric period, and loss of green colour and textural integrity. The findings of this study reveal the fact that light exposure can be used as an effective method for accelerating ripening during retail display, where consumers have a clear preference for 


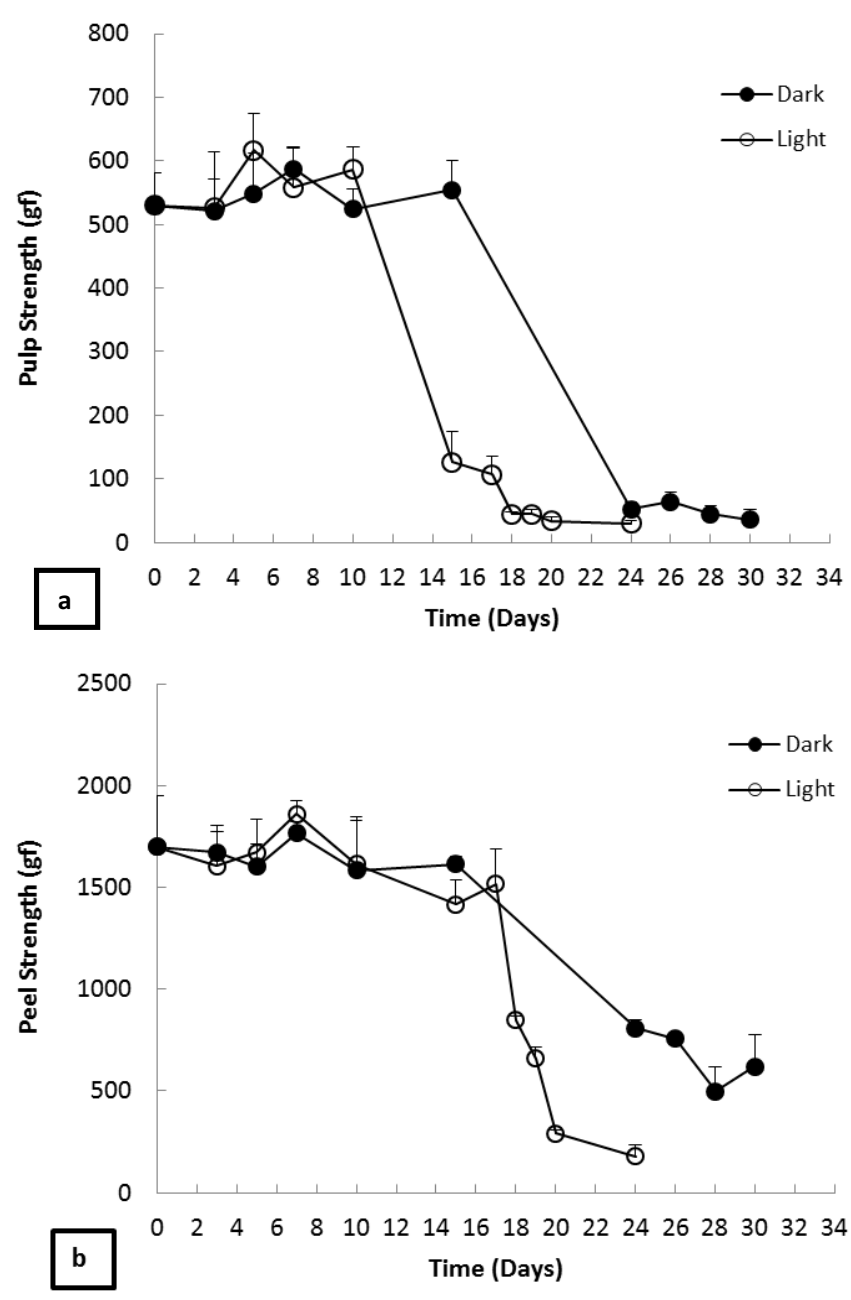

Figure 6. Change in the pulp (a) and peel (b) strength of banana fruits during postharvest storage under continuous light treatment of $24 \mu \mathrm{mol} \mathrm{m}{ }^{-2} \mathrm{~s}^{-1}(\circ)$ and darkness $(\bullet)$ at $20.5 \pm 1.0{ }^{\circ} \mathrm{C}$ and $22.0 \pm$ $1.0^{\circ} \mathrm{C}$, respectively. Data are the means \pm standard deviations $(n=3)$. The vertical bars indicate standard deviations.

ripe bananas. Besides, light treatment resulted in sweeter bananas, which is an important factor for consumer acceptance. However, further research is needed to elucidate the effect of light at different intensities, wavelengths and exposure periods on the keeping quality of bananas during postharvest handling.

\section{References}

[1] Ayala F., Echavarri J.F., Olarte C., Sanz S., Quality characteristics of minimally processed leek packaged using different films and stored in lighting conditions, Int. J. Food Sci. Technol. 44 (2009) 1333-1343.

[2] Büchert A.M., Gomez Lobato M.E., Effect of visible light treatments on postharvest senescence of broccoli (Brassica oleracea L.), J. Sci. Food Agric. 91 (2011) 355-361.

[3] Zhan L., Hu H., Pang L., Li Y., Zhu M., Light exposure during storage preserving soluble sugar and 1-ascorbic acid content of minimally processed romaine lettuce (Lactuca sativa L.var. longifolia), Food Chem. 136 (2013) 273-278.
[4] Arisoy E., Kahraman S., Okten C., Demiray F., A refrigerator with a light source irradiating the food therein, Patent, WIPO, WO/2007/068645, 2007.

[5] Moriya S., Nakamura T., Kasuya S., Irradiation device for preserving vegetable, Patent, JP20030301629 20030826 (2005).

[6] Sano S., Refrigerator, Patent, JP20030403993 20031203 (2005).

[7] Lester G.E., Makus D.J., Hodges D.M., Relationship between fresh-packaged spinach leaves exposed to continuous light or dark and bioactive contents: Effects of cultivar, leaf size, and storage duration, J. Agric. Food Chem. 58 (2010) 2980-2987.

[8] Toledo M.E.A.,Ueda Y., Imahori Y., Ayaki M., L-ascorbic acid metabolism in spinach (Spinacia oleracea L.) during postharvest storage in light and dark, Postharvest Biol. Technol. 28 (2003) 47-57.

[9] Liu L.H., Zarabas D., Bennett L., Aguas P., Wooton B.W., Effects of UV-C, red light and sun light on the carotenoid content and physical qualities of tomatoes during post-harvest storage, Food Chem. 115 (2009) 495-500.

[10] Zhan L., Hu J., Li Y., Pang L., Combination of light exposure and low temperature in preserving quality and extending shelflife of fresh-cut broccoli (Brassica oleracea L.), Postharvest Biol. Technol. 72 (2012) 76-81.

[11] Zhan L., Hu J., Lim L.-T., Pang L., Shao J., Light exposure inhibiting tissue browning and improving antioxidant capacity of fresh-cut celery (Apium graveolens var. dulce), Food Chem. 141 (2013) 2473-2478.

[12] Zhan L., Hu J., Lim L.-T., Pang L., Shao J., Light exposure reduced browning enzyme activity and accumulated total phenols in cauliflower heads during cool storage, Postharvest Biol. Technol. 88 (2014) 17-20.

[13] Sanz S., Olarte C., Ayala F., Echavarri J.F., The response to lighting of minimally processed chard: Influence on its shelf life, J. Sci. Food Agric. 88 (2008) 1622-1631.

[14] Olarte C., Sanz S., Echavarri J.F., Ayal F., Effect of plastic permeability and exposure to light during storage on the quality of minimally processed broccoli and cauliflower, LWT - Food Sci. Technol. 42 (2009) 402-411.

[15] Barbieri G., Bottino A., Orsini F., De Pascale S., Sulfur fertilization and light exposure during storage are critical determinants of the nutritional value of ready-to-eat friariello campano (Brassica rapa L. subsp. sylvestris), J. Sci. Food Agric. 89 (2009) 2261-2266.

[16] Sanz S., Olarte C., Ayala F., Echavarri J.F., Evolution of quality characteristics of minimally processed asparagus during storage in different lighting conditions, J. Food Sci. 74 (2009) S296-S302.

[17] Martinez-Sanchez A., Tudela J.A., Luna C., Allende A., Gil M.I., Low oxygen levels and light exposure affect quality of fresh-cut Romaine lettuce, Postharvest Biol. Technol. 59 (2011) 34-42.

[18] Costa L., Montano Y.M., Carrioni C., Rolny N., Guiamet J.J., Application of low intensity light pulses to delay postharvest senescence of Ocimum basilicum leaves, Postharvest Biol. Technol. 86 (2013) 181-191.

[19] Braidot E., Petrussa E., Peresson C., Patui S., Bertolini A., Tubaro F., Wählby U., Coan M., Vianello A., Zancani M., Low-intensity light cycles improve the quality of lamb's lettuce (Valerianella olitoria L. Pollich) during storage at low temperature, Postharvest Biol. Technol. 90 (2014) 15-23. 
[20] Xiao Z., Lester G.E., Luo Y., Xie Z.K., Yu L.L., Wang Q., Effect of light exposure on sensorial quality, concentrations of bioactive compounds and antioxidant capacity of radish microgreens during low temperature storage, Food Chem. 151 (2014) 472-479.

[21] Broughton W.J., Wu K.F., Storage conditions and ripening of two cultivars of banana, Sci. Hortic. 10 (1979) 83-93.

[22] Finger F.L., Puschmann R., Barros R.S., Effects of water loss on respiration, ethylene production and ripening of banana fruit, Revista Brasileira de Fisiologia Vegetal 7 (1995) 115-118.

[23] Liu S., Yang Y., Murayama H., Taira S., Fukushima T., Effects of $\mathrm{CO}_{2}$ on respiratory metabolism in ripening banana fruit, Postharvest Biol. Technol. 33 (2004) 27-34.

[24] Stewart O.J., Ragahavan G.S.V., Golden K.D., Gariepy Y., MA storage of Cavendish bananas using silicone membrane and diffusion channel systems, Postharvest Biol. Technol. 35 (2005) 309-317.

[25] Johnson B.E., Brun W.A., Stomatal density and responsiveness of banana fruit stomates, Plant Physiol. 41 (1966) 99-101.

[26] Zhu X., Shen L., Fu D., SI Z., Wu B., Chen W., Li X., Effects of the combination treatment of 1-MCP and ethylene on the ripening of harvested banana fruit, Postharvest Biol. Technol. 107 (2015) 23-32.

[27] Knee M., Hatfield S.G.S., Ratnayake M., Acceleration of some ripening processes by light treatment of stored apples, J. Exp. Bot. 30 (1979) 1013-1020.

[28] Foyer C.H., Shigeoka S., Understanding oxidative stress and antioxidant functions to enhance photosynthesis, Plant Physiol. 155 (2011) 93-100.

[29] Morgan P.W., Drew M.C., Ethylene and plant responses to stress, Physiol. Plant. 100 (1997) 620-630.
[30] Terra N.N., Garcia E., Lajolo F.M., Starch-sugar transformation during banana ripening: The behavior of UDP glucose pyrophosphorylase, sucrose synthetase and invertase, J. Food Sci. 48 (1983) 1097-1100.

[31] Cordenunsi B.R., Lajolo F.M., Starch breakdown during banana ripening: sucrose synthase and sucrose phosphate synthase, J. Agric. Food Chem. 43 (1995) 347-351.

[32] Hubbard N.L., Pharr D.M., Huber S.C., Role of sucrose phosphate synthase in sucrose biosynthesis in ripening bananas and its relationship to the respiratory climacteric, Plant Physiol. 94 (1990) 201-208.

[33] Kanellis A.K., Solomos T., Mattoo A.K., Changes in sugars, enzymic activities and acid phosphatase isoenzyme profiles of bananas ripened in air or stored in $2.5 \% \mathrm{O}_{2}$ with and without ethylene, Plant Physiol. 90 (1989) 251-258.

[34] Salvador A., Sanz T., Fiszman S.M., Changes in colour and texture and their relationship with eating quality during storage of two different dessert bananas, Postharvest Biol. Technol. 43 (2007) 319-325.

[35] Gomes J.F.S., Vieira R.R., Leta F.R., Colorimetric indicator for classification of bananas during ripening, Sci. Hortic. 150 (2013) 201-205.

[36] Ding P., Ahmad S.H., Razak A.R.A., Saari N., Mohamed M.T.M. Plastid ultrastructure, chlorophyll contents, and colour expression during ripening of cavendish banana (Musa acuminata 'Williams') at $18{ }^{\circ} \mathrm{C}$ and $27^{\circ} \mathrm{C}, \mathrm{N}$. Z. J. Crop Hortic. Sci. 35 (2007) 201-210.

[37] Pua E.-C., Ong C.-K., Liu P., Liu J.-Z., Isolation and expression of two pectate lyase genes during fruit ripening of banana (Musa acuminata), Physiol. Plant, 113 (2001) 92-99.

Cite this article as: İbrahim Sani Özdemir. Effect of light treatment on the ripening of banana fruit during postharvest handling. Fruits 71 (2016) 115-122. 